\title{
Nutrient limitation of phytoplankton in Chesapeake Bay
}

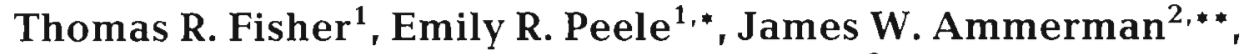 \\ Lawrence W. Harding, $\mathrm{Jr}^{3}$
}

\footnotetext{
${ }^{1}$ Horn Point Environmental Labs, University of Maryland-CEES, Cambridge, Maryland 21613, USA

${ }^{2}$ Lamont-Doherty Geological Observatory, Columbia University, Palisades, New York 10964, USA

${ }^{3}$ Sea Grant College, University of Maryland, College Park, Maryland 20742, USA
}

\begin{abstract}
This paper presents evidence of a seasonal shift from $P$ to $N$ as the nutrient limiting the accumulation of algal biomass in Chesapeake Bay. Following the winter/spring maximum in freshwater runoff, (1) the ratio of dissolved inorganic nitrogen to soluble reactive phosphorus (DIN/PO 4 ) was greater than the N/P of algal biomass; (2) alkaline phosphatase activity was high; (3) phosphate turnover times were short; (4) ammonium turnover times were long; and (5) growth rates of phytoplankton were stimulated by additions of phosphate but not by additions of ammonium or silicate. During the period of low runoff in summer, all indicators reversed, and $\mathrm{N}$ limited algal growth rates. Silicate concentrations also showed evidence of biological depletion in spring, which may have limited diatom abundance. Due to the concordance of all indicators at large and small scales, we argue that phytoplankton growth rates exert primary control over biomass accumulation. We conclude that $\mathrm{P}$ and Si limit the accumulation of algal biomass along the major axis of Chesapeake Bay in spring, whereas $N$ limits algal accumulation in summer, similar to the conclusions of D'Elia et al. (1986; Can. J. Fish. Aquat. Sci. 43: 397-406) for the Patuxent subestuary. Controlling eutrophication of the Bay and its subestuaries will require basin-specific management practices for both $N$ and $P$ reductions in influent waters. Such management efforts will provide ecosystem tests of nutrient limitation on a scale similar to those successfully conducted in lakes.
\end{abstract}

\section{INTRODUCTION}

Cultural eutrophication of lakes and estuaries results from anthropogenic inputs of nitrogen $(\mathrm{N})$ and phosphorus (P) from surrounding watersheds (Edmondson 1970, Schindler 1977, Oglesby \& Schaffner 1978, Smith 1982, Hecky \& Kilham 1988). While there has been considerable experimental work on the causes of lake eutrophication over the last few decades (e.g. Vollenweider 1968, Schindler 1977), less attention has been focused on estuaries, probably due to their larger size, spatial heterogeneity, open connection with the sea, and lack of replication or controls.

Estuaries, however, are increasingly subjected to anthropogenic nutrient stress. For example, Chesapeake Bay, the largest estuary in the USA,

Present addresses:

- Dept. of Biology, Western Washington University, Bellingham, Washington 98225, USA

- Dept. of Oceanography, Texas A\&M University, College Station, Texas 77843-3146, USA exhibits symptoms of cultural eutrophication similar to those observed in lakes (US EPA 1982). Forest removal and anthropogenic activities in the watershed contribute eroded soil, $\mathrm{N}$, and $\mathrm{P}$ to Bay waters, and phytoplankton biomass accumulates, resulting in high sedimentation rates of organic material and oxygen depletion during decomposition (Boynton et al. 1982, Brush \& Davis 1984, Seliger et al. 1985, Malone et al. 1986, 1988, Fisher 1989, Cooper \& Brush 1991). N and P loading also contributes to the decline in submerged aquatic vegetation by stimulating the growth of planktonic and epiphytic algae, which shade the plants (Orth \& Moore 1983).

$\mathrm{N}$ and $\mathrm{P}$ entering Chesapeake Bay are efficiently converted into phytoplankton biomass. Of the readily available forms of these nutrients $\left(\mathrm{NH}_{4}, \mathrm{NO}_{3}, \mathrm{PO}_{4}\right), 75$ to $95 \%$ are consumed downstream of the turbidity maximum in the more transparent mesohaline waters (Fisher et al. 1988). The resulting algal biomass is either consumed, buried in sediments, or exported to the continental shelf (Nixon 1987, Fisher et al. 1988). 
There is controversy concerning the relative roles of $\mathrm{N}$ and $\mathrm{P}$ in regulating phytoplankton biomass in estuaries (Smith 1984, Caraco 1988, Howarth 1988, Webb 1988). Although most lakes appear to be Plimited (e.g. Schindler 1977), marine waters are considered N-limited (Howarth 1988). Caraco et al. (1990) have hypothesized that the difference between marine and freshwater systems is related to the lower phosphorus immobilization capacity of marine sediments and the higher concentrations of sulphate. In estuaries, coastal ponds, fjords, and coastal areas which have seasonally varying mixtures of fresh- and seawater, there is evidence for seasonal and spatial variations in the limiting nutrient (D'Elia et al. 1986, Caraco et al. 1987, Caraco 1988, Paasche \& Erga 1988, Webb 1988 Harrison et al. 1990). As examples, in the Patuxent and York subestuaries of Chesapeake Bay, mesoscale bioassays indicated $\mathrm{P}$ limitation during winter and spring and $N$ limitation during summer (D'Elia et al. 1986, Webb 1988). However, the production of algal biomass in response to experimental $\mathrm{P}$ addition was considered to be weak and delayed in the Patuxent (D'Elia et al. 1986, Webb 1988). The weak P limitation may have been the result of large volumes of P-rich wastewater discharge, which account for ca $7 \%$ of the freshwater inflows to the estuary from this heavily settled basin (Domotor et al. 1989).

These apparent seasonal shifts in the limiting nu trient may be due to large seasonal and spatial variations in nutrient loading. In estuaries with developed basins, there are large seasonal variations in freshwater runoff with a high N/P ratio and a more constant flow of sewage with a low N/P (Magnien et al. 1987, Fisher 1989). For example, in the Choptank River, a subestuary of Chesapeake Bay, the N/P of total nutrient inputs declined from winter to summer, as river discharge decreased (Fisher 1989). In the Rhode River subestuary of Chesapeake Bay, Jordan et al. (1991) have also demonstrated conversion of particulate $\mathrm{P}$ to soluble reactive phosphate in the oligohaline area at warmer temperatures, a process which lowers the N/P of nutrients.

The purpose of the research reported here was to investigate the relative roles of $\mathrm{N}$ and $\mathrm{P}$ in controlling the accumulation of algal biomass in the major axis of Chesapeake Bay. In contrast to the Patuxent subestuary, the major north/south axis of Chesapeake Bay is less influenced by wastewater inflows (US EPA 1982, Magnien et al. 1987), and algal biomass and productivity have been correlated with Susquehanna River discharge and $\mathrm{N}$ inputs (Malone et al. 1988). Here we test the hypothesis that along the main axis of the Chesapeake, P limits accumulation of phytoplankton biomass following the spring runoff maximum (high $\mathrm{N} / \mathrm{P}$ of nutrient inputs), and that $\mathrm{N}$ limits biomass accumulation under conditions of lower summer runoff (lower N/P of nutrient inputs). We present the following evidence: (1) concentrations of dissolved inorganic nutrients, (2) turnover times of inorganic $N$ and $P,(3)$ alkaline phosphatase activities, and (4) nutrient enrichment bioassays

\section{METHODS}

We participated in research cruises on RVs 'Cape Hatteras', 'Aquarius', and 'Warfield' along the main stem of Chesapeake Bay between 1982 and 1988. Water samples were obtained in $10 \mathrm{l}$ Van Dorn bottles or by submersible pump after making vertical profiles of water column density structure with in situ measurements of temperature $\left({ }^{\circ} \mathrm{C}\right.$ ) and salinity (psu = practical salinity units). Subsamples for nutrient analyses were filtered through Gelman A/E or Whatman GF/F glass fiber filters under low vacuum $(<15 \mathrm{~cm} \mathrm{Hg})$; duplicates were analyzed immediately on board ship using a Technicon AutoAnalyzer ('Cape Hatteras') or were filtered, frozen, and processed ashore in a Technicon AutoAnalyzer II ('Aquarius', 'Warfield').

Turnover times of ammonium and phosphate were measured using ${ }^{15} \mathrm{~N}-\mathrm{NH}_{4}$ and ${ }^{32} \mathrm{P}_{-} \mathrm{PO}_{4}$. Incubations with ${ }^{15} \mathrm{~N}-\mathrm{NH}_{4}$ were done on deck at $60 \%$ of ambient sunlight, and incubations with ${ }^{32} \mathrm{P}_{-} \mathrm{PO}_{4}$ were usually done in lab

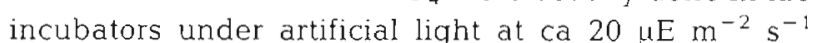
because of the more rapid sampling required. Ammonium uptake and regeneration were measured in time series measurements as described in Fisher \& Morrissey (1985), and tumover times were computed from regeneration rates and ambient $\left[\mathrm{NH}_{4}\right]$. Phosphate turnover time was directly computed from time series measurements of filtrate ${ }^{32} \mathrm{P}$ activity as in Lean (1973).

Alkaline phosphatase activity was measured in duplicate by the fluorometric method of Hoppe (1983), using $100 \mathrm{nM} 4$-methylumbelliferyl phosphate as the substrate. Samples were incubated under temperaturecontrolled, reduced-light conditions in the lab, and substrate turnover times were computed from shortterm time course measurements made over ca 10 to 60 min. Additional details of the method are described in Ammerman \& Azam (1991).

Nutrient enrichment bioassays were used to examine nutrient limitation of phytoplankton growth rates. Although we did not directly measure growth rates, we used changes in algal biomass and fixation of $\mathrm{CO}_{2}$ as indicators of change in growth rates. Four 31 subsamples of the surface water of each station were placed in 4 l cubetainers. One subsample served as a control (no additions), and the other 3 received additions of $\mathrm{NH}_{4}$, $\mathrm{PO}_{4}$, or $\mathrm{NH}_{4}+\mathrm{PO}_{4}$. These additions increased nutrient concentrations within the cubetainers by $30 \mu \mathrm{M} \mathrm{NH}$ and $2 \mu \mathrm{M} \mathrm{PO}_{4}$ to saturate nutrient uptake and relieve 
nutrient limitation. After incubations for $24 \mathrm{~h}$ at $60 \%$ of ambient sunlight in an on-deck incubator, changes in growth rate were estimated from changes in chlorophyll a concentrations measured fluorometrically in duplicate (Lorenzen 1967) and photosynthetic capacity measured in duplicate as ${ }^{14} \mathrm{C}-\mathrm{CO}_{2}$ incorporation at $200 \mu \mathrm{E} \mathrm{m}^{-2} \mathrm{~s}^{-1}$ for $1 \mathrm{~h}$. All responses were expressed as percent of control.

\section{RESULTS}

\section{Dissolved inorganic nutrients}

There were significant seasonal variations in salinity along the major axis of the Bay which were caused by variations in Susquehanna River flow. March and April are typically the months of maximum freshwater inflow, and an example is shown for 1987 in Fig. 1. In May 1987, following maximum river discharge, the surface mixed layer of the Bay was more than $75 \%$ freshwater in the first $100 \mathrm{~km}$ downstream from the Susquehanna River (Fig. 2) and ca $65 \%$ freshwater (ca $12 \mathrm{psu}$ ) for the remaining $200 \mathrm{~km}$ length. By August 1987, during the annual minimum in river flow (Fig. 1), surface salinities were 5 to 10 psu higher throughout the Bay (Fig. 2), indicating that seawater comprised about one half the volume of surface waters

$N$ and $P$ concentrations differed considerably between seasons. Fig. 3 shows an example of dissolved inorganic nitrogen ( $\mathrm{DIN}=\mathrm{NH}_{4}+\mathrm{NO}_{2}+\mathrm{NO}_{3}$ ), soluble reactive phosphate $\left(\mathrm{PO}_{4}\right)$, and reactive silicate $\left(\mathrm{SiO}_{4}\right)$ in surface waters along the length of Chesapeake Bay at the same times as in Fig. 2. DIN was highest (>20 $\mu \mathrm{M})$ near the Susquehanna River at both times of the year however, in May 1987, when freshwater dominated the Bay water composition (Fig. 2), DIN was $>10 \mu \mathrm{M}$ throughout the Bay except near the oceanic end. In contrast, in August 1987, DIN was nearly depleted throughout the Bay $(<2 \mu \mathrm{M})$, except near the Susquehanna River. $\mathrm{PO}_{4}$ was low throughout the Bay at both times of the year $(0.01$ to $0.50 \mu \mathrm{M})$; lowest concentrations $(<0.1 \mu \mathrm{M})$ were found in the middle of the Bay in both May and August, and $\mathrm{PO}_{4}$ was slightly higher overall in August than in May. In May 1987, silicate was nearly depleted $(<2 \mu \mathrm{M})$, except from $\mathrm{km} 20$ to 130 and $\mathrm{km} 180$ to 220 . The depletion at the river mouth may have been due to a transient diatom bloom in the reservoirs of the Susquehanna River, based on water quality data for the Susquehanna River (US Geological Survey 1987). $\mathrm{SiO}_{4}$ concentrations were higher overall in August than in May 1987, despite lower river flows (Fig. 1). These results are similar to those previously reported for Bay waters (e.g. Taft \& Taylor 1976a, Taft et al. 1978, D'Elia et al. 1983, Fisher et al. 1988).

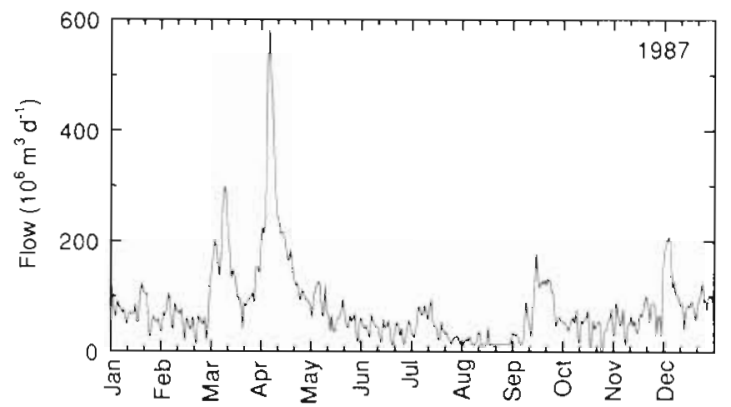

Fig. 1. Discharge of the Susquehanna River at Conowingo Dam. Data courtesy of US Geological Survey (1987)

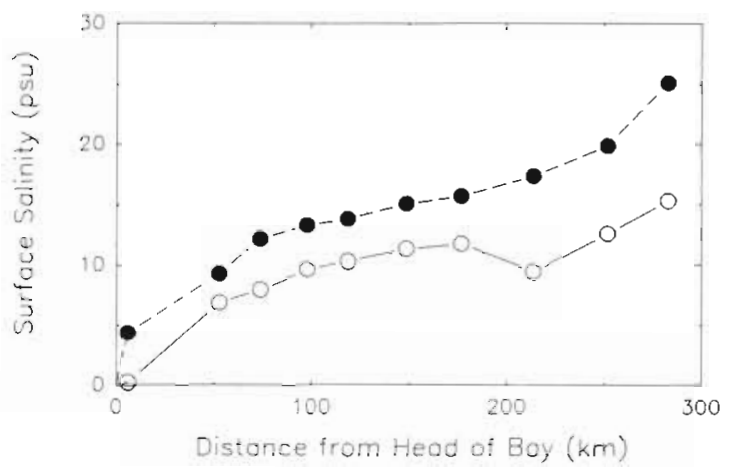

Fig. 2. Spatial distribution of salinity in surface waters along the length of Chesapeake Bay in May (_) and August $(\bullet-\bullet) 1987$

The DIN/PO ${ }_{4}$ ratio changed both seasonally and spatially (Fig 4). In May 1987, DIN/PO 4 was greater than the algal N/P (Redfield ratio) throughout most of the Bay, declining to $<16: 1$ only near the ocean. In August, DIN/PO ${ }_{4}$ was $<16: 1$ over much of the length of the Bay, except near the Susquehanna River, where freshwater dominated (Fig. 2).

The $\mathrm{SiO}_{4} / \mathrm{PO}_{4}$ ratio underwent more complex seasonal changes. We assume here an N:Si of $1: 1$ for diatoms, and thus a $\mathrm{SiO}_{4} / \mathrm{PO}_{4}$ of $16: 1$ for balanced growth (D'Elia et al. 1983). In May 1987, $\mathrm{SiO}_{4} / \mathrm{PO}_{4}$ was $<16: 1$ in 3 regions: (1) near the river mouth, (2) in the middle of the Bay, and (3) near the oceanic end. A similar but much less pronounced pattern and generally higher ratios were observed in August, suggesting less demand for $\mathrm{SiO}_{4}$ relative to $\mathrm{PO}_{4}$. This is consistent with high proportions of Si-requiring diatoms in the phytoplankton community in spring, and primarily non-siliceous forms in summer (Sellner 1987).

The data in Figs. 1 to 4 are typical of other years. In Table 1 we have summarized nutrient data from 1982 to 1988 that are similar to those shown in Figs. 3 \& 4 . Due to the spatial variability in nutrient concentrations and ratios, we have indicated the ranges where the curve fitted to the data falls below either the approximate half-saturation constants for uptake (DIN $\approx 2 \mu \mathrm{M}$, 
May ' 87
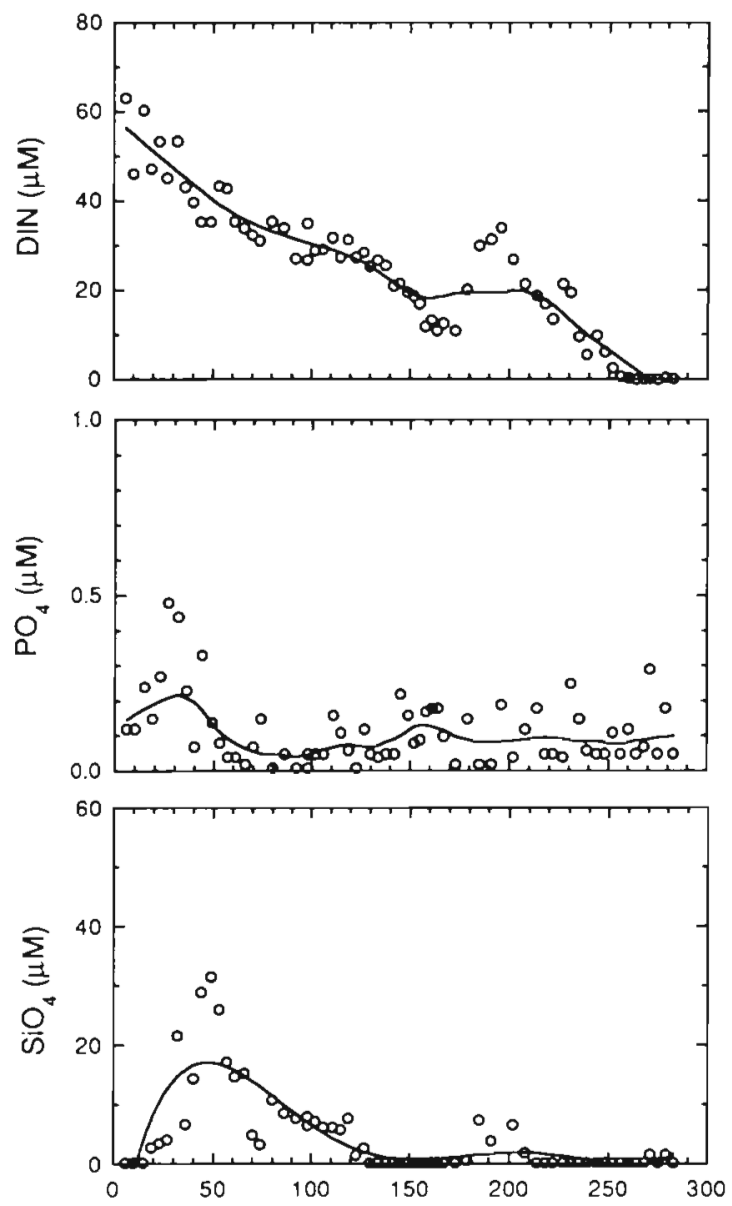

Aug ' 87
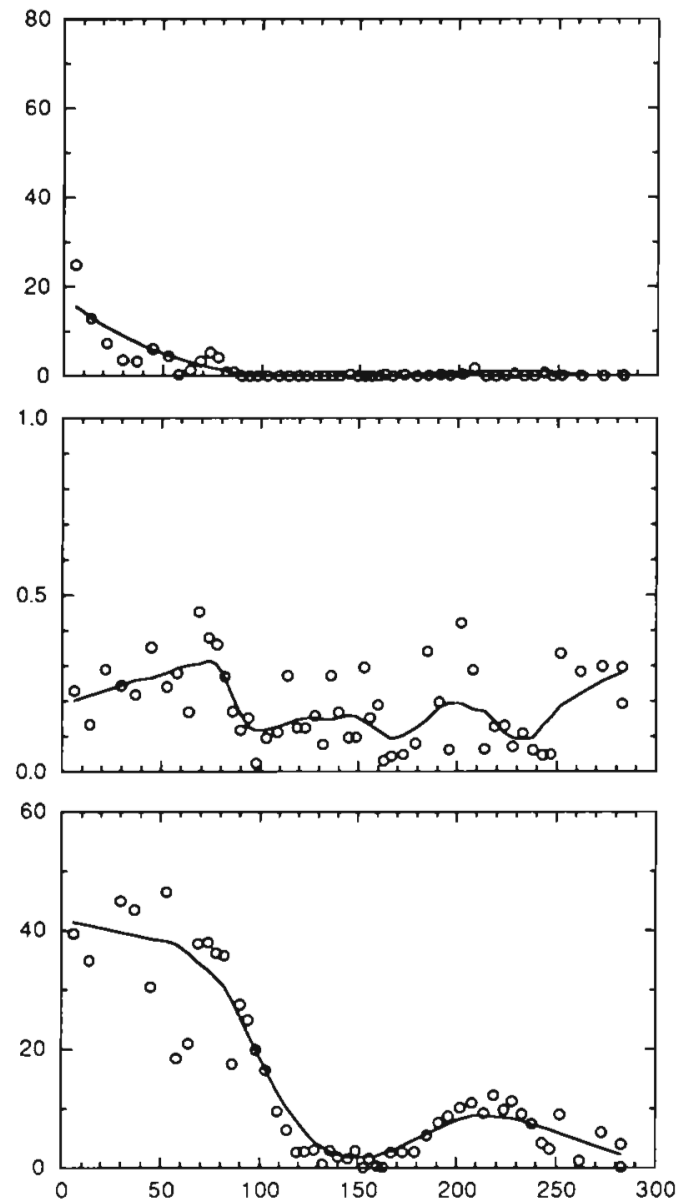

Distance from Head of Bay $(\mathrm{km})$

Fig. 3. Spatial distributions of dissolved inorganic nitrogen (DIN $=$ nitrate + nitrite + ammonium), soluble reactive phosphate $\left(\mathrm{PO}_{4}\right)$, and reactive silicate $\left(\mathrm{SiO}_{4}\right)$ in surface waters of the Chesapeake Bay in May and August 1987. Lines were polynomial equations fitted to the data to average spatial variability

$\mathrm{PO}_{4} \approx 0.2 \mu \mathrm{M}, \mathrm{SiO}_{4} \approx 2 \mu \mathrm{M}_{i}$ see Fisher et al. 1988) or the 16:1 ratio for phytoplankton composition. In all spring cruises, $\mathrm{PO}_{4}$ was depleted $(<0.2 \mu \mathrm{M})$ and excess DIN was available ( $>2 \mu \mathrm{M}$ ) over much of the length of the Bay. In August, DIN was depleted $(<2 \mu \mathrm{M})$ over at least half of the Bay's length, and $\mathrm{PO}_{4}$ concentrations were depleted over smaller ranges than in spring, except in July 1982. Accordingly, DIN/PO 4 was $>16: 1$ over most of the Bay's length in spring, and $<16: 1$ over most of the Bay's length in summer. Similarly, $\mathrm{SiO}_{4}$ was depleted over significant ranges in spring $(<2 \mu \mathrm{M})$, but was abundant in summer. $\mathrm{SiO}_{4} / \mathrm{PO}_{4}$ was $<16: 1$ in sections of the Bay in spring (except May 1986), but was $<16: 1$ over a much more limited range in summer

Biological availability of the nutrients influences the interpretation of these ratios. Although $\mathrm{NH}_{4}, \mathrm{NO}_{2}, \mathrm{NO}_{3}$, and $\mathrm{SiO}_{4}$ are normally considered biologically available, there is considerable evidence from fresh water research that soluble reactive $\mathrm{PO}_{4}$ contains both a biologically available component (true orthophosphate) plus a chemically bound fraction that is extracted by the reagents used in the analysis (Rigler 1966, 1973, Cembella et al. 1984). Biologically available $\mathrm{PO}_{4}$ has been shown to vary from 10 to $100 \%$ of soluble reactive $\mathrm{PO}_{4}$ in the Chesapeake (Fisher et al. unpubl.). Therefore, chemical measurements of soluble reactive $\mathrm{PO}_{4}$ overestimate the biologically available fraction, and the ratios of biologically available DIN/ $\mathrm{PO}_{4}$ and $\mathrm{SiO}_{4}$ are even higher than those illustrated in Fig. 4 and summarized in Table 1.

These data may be used to infer the potential for nutrient limitation in Chesapeake Bay. The observed changes in concentrations of DIN and $\mathrm{PO}_{4}$ and in DIN/ $\mathrm{PO}_{4}$ represent an ecosystem response, i.e. the net result of seasonal river flow, ocean water dilution, constant wastewater flow, and internal biogeochemical processing (e.g. uptake, regeneration, nitrification, denitrification, etc.). The data show excess DIN throughout 
most of the Bay in spring, and low nutrient concentrations in summer with an apparent excess of $\mathrm{PO}_{4}$ (Figs. $3 \& 4$ ). The ratio indicates the potential for widespread $\mathrm{P}$ limitation of algal growth throughout most of the Bay in spring (DIN/PO $>$ algal $\mathrm{N} / \mathrm{P}$ ) and $\mathrm{N}$ limita-

\section{May ' 87}
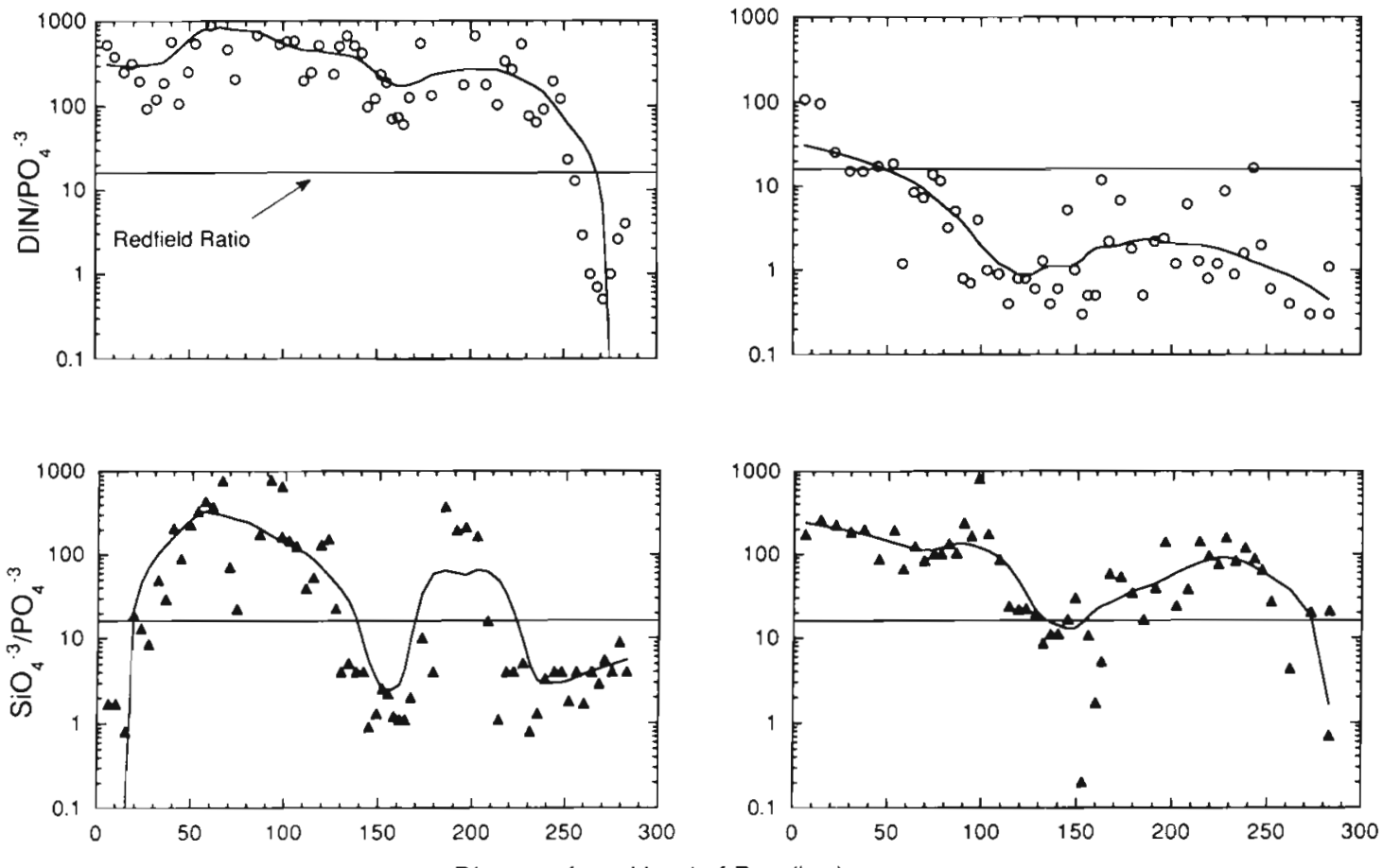

Fig. 4. Nutrient ratios for the data displayed in Fig. 3. The algal N/P of $16: 1$ is indicated by the horizontal line, and a polynomial was fitted to the data as in Fig. 3.

Table 1. Summary of nutrient distributions along transects of the major axis of Chesapeake Bay from the Susquehanna River mouth ( $\mathrm{km} 0)$ to the Bay mouth at Capes Charles and Henry ( $\mathrm{km} \mathrm{300).} \mathrm{Values} \mathrm{given} \mathrm{are} \mathrm{the} \mathrm{ranges,} \mathrm{in} \mathrm{km} \mathrm{of} \mathrm{Bay} \mathrm{length,} \mathrm{over}$ which dissolved inorganic nitrogen (DIN), soluble reactive phosphate $\left(\mathrm{PO}_{4}\right)$, and reactive silicate $\left(\mathrm{SiO}_{4}\right)$ fell below approximate half-saturation constants for uptake $(2,0.2$, or $2 \mu \mathrm{M}$, respectively, concentrations potentially limiting to algal growth). Also shown are the distance ranges over which DIN/PO 4 or $\mathrm{SiO}_{4} / \mathrm{PO}_{4}$ fell below the Redfield ratio (algal compositional ratio of $16: 1$ by atoms). Multiple lines of values under one date indicate multiple ranges, as in Figs. $3 \& 4$. Distances shown as $>x x x$ indicate that the range extends from $x x x \mathrm{~km}$ to the end of the transect at the Bay mouth; if $x x x=300$, the condition was not observed within the Bay

\begin{tabular}{|c|c|c|c|c|c|}
\hline Date & DIN $<2$ & $\mathrm{PO}_{4}<0.2$ & $\mathrm{SiO}_{4}<2$ & $\mathrm{DIN} / \mathrm{PO}_{4}<16$ & $\mathrm{SiO}_{4} / \mathrm{PO}_{4}<16$ \\
\hline \multicolumn{6}{|c|}{ Spring (April-May) } \\
\hline Apr 1983 & $>260$ & $>80$ & $>160$ & $>260$ & $160-290$ \\
\hline May 1986 & $>300$ & $>80$ & $>300$ & $>300$ & $>300$ \\
\hline May 1987 & $>250$ & $>10$ & $0-20$ & $>270$ & $0-20$ \\
\hline & & & $\begin{array}{c}130-180 \\
>210\end{array}$ & & $\begin{array}{c}130-180 \\
>210\end{array}$ \\
\hline May 1988 & $>210$ & $>30$ & $>150$ & $>250$ & $150-270$ \\
\hline \multicolumn{6}{|c|}{ Summer (July-August) } \\
\hline Jul 1982 & $>140$ & $>70$ & $>300$ & $>300$ & $>300$ \\
\hline Aug 1986 & $>140$ & $>300$ & $>300$ & $>50$ & $>220$ \\
\hline Aug 1987 & $>80$ & $100-260$ & $>280$ & $>50$ & $\begin{array}{c}130-160 \\
>270\end{array}$ \\
\hline Aug 1988 & $>120$ & $160-280$ & $>300$ & $\begin{array}{l}70-170 \\
>280\end{array}$ & $>300$ \\
\hline
\end{tabular}


be emphasized that concentrations and elemental ratios can only indicate which nutrient(s) potentially limit growth rates or biomass accumulation on some time scale; data on rate processes such as those described below are needed to support what the above data suggest.

\section{Nutrient turnover times}

Nutrient turnover times can be used to support inferences of nutrient limitation because the measurements integrate the effects of external concentrations, internal storage, and biomass (Lean et al. 1987, 1989). If the nutrient concentration is high and uptake rates are low, the turnover time is long, indicating a large supply relative to demand. Conversely, under nutrient stress, concentrations are low, uptake rates are elevated, and turnover times of the pools are short, indicating a small supply relative to demand. For instance, phosphate tumover times $<10$ min $(<0.17 \mathrm{~h})$ have been used to indicate $\mathrm{P}$ limitation (Lean et al. 1987).

There were large seasonal variations in nutrient turnover times of surface waters at 6 stations in Chesapeake Bay (Table 2). $\mathrm{NH}_{4}$ turnover times were 100 to $1000 \mathrm{~h}$ (1 to $3 \mathrm{wk}$ ) in March, decreased to between 10 and $100 \mathrm{~h}$ (except in the turbid northern Bay) by April-May, and were shortest (1 to $10 \mathrm{~h})$ in July-August when DIN was virtually depleted (Fig 3). In contrast, $\mathrm{PO}_{4}$ turnover times were intermediate in March, shortest in April-May, varying from 3 to $10 \mathrm{~min}$ (except in the light-limited northern Bay), and lengthened to between 2 and $20 \mathrm{~h}$ during July-August. In both spring and summer, turnover times of $\mathrm{NH}_{4}$ and $\mathrm{PO}_{4}$ were shortest in the middle of the Bay (100 to 200 $\mathrm{km}$ ). Taft et al. (1975) reported similar turnover times for $\mathrm{PO}_{4}$ in Chesapeake Bay. These nutrient turnover times indicate the lowest $\mathrm{P}$ supply relative to demand in spring, when DIN was present in excess (Fig. 3), and the lowest $N$ supply relative to demand in summer, when DIN was depleted (Fig. 3).

\section{Alkaline phosphatase activity}

Planktonic alkaline phosphatase activity provided added evidence of seasonal changes in the limiting nutrient (Table 2). The enzyme alkaline phosphatase catalyzes the dephosphorylation of organic P compounds, permitting utilization of the hydrolyzed $\mathrm{PO}_{4}$. Enzyme activity is induced by $\mathrm{P}$ deficiency, and short turnover times for alkaline phosphatase substrates suggest P limitation (Cembella et al. 1984, Ammerman \& Azam 1985). In Chesapeake Bay, turnover times of alkaline phosphatase substrates were short in spring, generally $<4 \mathrm{~h}$, and averaged $2.6 \mathrm{~h}$ from March through May. However, turnover times increased more than an order of magnitude in July-August and were generally $>10 \mathrm{~h}$, averaging $35 \mathrm{~h}$. Taft et al. (1977) also reported similar seasonal changes in alkaline phosphatase activity in Chesapeake Bay.

Examination of phosphatase activity in the nutrient bioassays (see below) revealed further details. The experimental additions of $\mathrm{NH}_{4}$ from March to May had little effect on turnover times of alkaline phosphatase substrates, although additions of $\mathrm{PO}_{4}$ significantly lengthened turnover times. In contrast, $\mathrm{NH}_{4}$ additions in August shortened turnover times of phosphatase substrates by more than a factor of 10, making them similar to turnover times in winter-spring. Additions of $\mathrm{PO}_{4}$ had much less effect in summer than in spring. These experimental manipulations suggest that phosphatase enzyme activity was near-maximal under $\mathrm{P}$. limited conditions in spring but that enzyme activity was suppressed under summer $\mathrm{N}$ limitation. The $\mathrm{NH}_{4}$ additions in summer may have alleviated $N$ limitation and induced P stress, as previously suggested by Taft \& Taylor (1976b) in similar experimental manipulations.

\section{Nutrient enrichment bioassays}

We obtained a range of bioassay responses, which we categorized into 5 classes. Responses to additions of

Table 2. Average values of turnover times of ammonium, phosphate, and substrates of alkaline phosphatase in surface waters of Chesapeake Bay during late winter, spring, and summer between 1982 and 1987 ( $\mathrm{n}=1$ to 3 per time period); km indıcates the approximate distance down the mainstem of Chesapeake Bay from the Susquehanna River

\begin{tabular}{|c|c|c|c|c|c|c|c|c|c|}
\hline \multirow[t]{2}{*}{$\mathrm{km}$} & \multicolumn{3}{|c|}{$\mathrm{NH}_{4}$} & \multicolumn{3}{|c|}{$\mathrm{PO}_{4}$} & \multicolumn{3}{|c|}{ Alkaline phosphatase substrates } \\
\hline & Mar & Apr-May & Jul-Aug & Mar & Apr-May & Jul-Aug & Mar & Apr-May & Jul-Aug \\
\hline 6 & 470 & - & 7.2 & - & 1.6 & 8.7 & - & 6.4 & 62. \\
\hline 74 & 1000 & 530 & 5.4 & - & 0.16 & 12. & - & 3.3 & 8.3 \\
\hline 119 & - & 12 & 1.1 & 0.87 & 0.13 & 6.2 & 3.8 & 2.6 & 12. \\
\hline 177 & - & 41 & 3.1 & - & - & 1.9 & - & 0.9 & 25. \\
\hline 214 & 147 & - & - & - & - & 2.8 & - & 0.7 & 33. \\
\hline 283 & - & 60 & - & - & 0.06 & 21 & - & 0.7 & 71 \\
\hline
\end{tabular}


$\mathrm{NH}_{4}$ and/or $\mathrm{PO}_{4}$ after $24 \mathrm{~h}$ were measured as increases in chlorophyll $a$ and $\mathrm{CO}_{2}$ fixation relative to controls with no nutrient additions at 6 stations. Algal biomass in surface waters and approximate station locations are indicated in Fig. 5. Bioassay results were categorized as shown in Fig. 6. We defined 'exclusive' P or $\mathrm{N}$ limitation of phytoplankton growth rates as having occurred when (1) addition of the other nutrient induced no response relative to the control, and (2) addition of the exclusive limiting nutrient had virtually the same effect as the addition of both. 'Primary' $\mathrm{N}$ or $\mathrm{P}$ limitation of growth rates was defined as (1) little response to the other nutrient alone, (2) a significant response to addition of the primary nutrient, and (3) the largest response to the addition of both nutrients. The last class was that of no response, usually in the turbid and nutrient-rich northern Bay. Although not specifically tested in the data presented here, subsequent studies using similar bioassays in Chesapeake Bay showed that the species increasing in biomass in response to nutrient additions were those dominating the planktonic populations at the time of sampling. In 5 bioassays exhibiting the full range of responses shown in Fig. 5 , there were no major taxonomic shifts or blooms of previously unimportant species (Fisher et al. 1992).

Results from the nutrient enrichment bioassays were consistent with other evidence of seasonal changes in the limiting nutrient (Table 3). During May 1987 at the turbid and nutrient-rich northern end of the Bay near the Susquehanna River (Fig. 3), there were no responses to any nutrient additions. At the next 2 stations downbay in May 1987 (see Fig. 5), there were no significant responses to $\mathrm{NH}_{4}$ additions, either alone or in combination with $\mathrm{PO}_{4}$; however, there were large responses to $\mathrm{PO}_{4}$ additions (exclusive $\mathrm{P}$ limitation of growth rate; Fig. 6, km 119). The lower biomass in the middle of the Bay from $\mathrm{km} 50$ to 150 (Fig. 5) may have been caused by $\mathrm{P}$ limitation of growth rates. At the seaward end of the Bay, additions of $\mathrm{NH}_{4}+\mathrm{PO}_{4}$ stimulated production of chlorophyll $a$ and $\mathrm{CO}_{2}$ fixation more than additions of $\mathrm{PO}_{4}$ alone (primary $\mathrm{P}$ limitation; Fig. $6, \mathrm{~km} 283$ ). The higher biomass at the seaward end of the Bay (Fig. 5) may have been the result of partial alleviation of $P$ limitation by seawater inflows or other inputs (e.g. James River, Norfolk sewage inflows).

In August 1987 conditions were reversed (Table 3). Additions of $\mathrm{PO}_{4}$ had little effect on growth rate, and $\mathrm{NH}_{4}$ additions stimulated both an increase in phytoplankton biomass and $\mathrm{CO}_{2}$ fixation relative to controls (Fig. 6). No bioassay was done at $\mathrm{km} 6$, but at the next 3 stations downbay (see Fig. 5) algal populations showed evidence of primary $\mathrm{N}$ limitation of growth rate (Fig. 6 , $\mathrm{km} \mathrm{177).} \mathrm{At} \mathrm{the} 2$ most seaward stations, there was no response to $\mathrm{PO}_{4}$ alone or in combination with $\mathrm{NH}_{4}$ i however, strong responses to additions of $\mathrm{NH}_{4}$ were

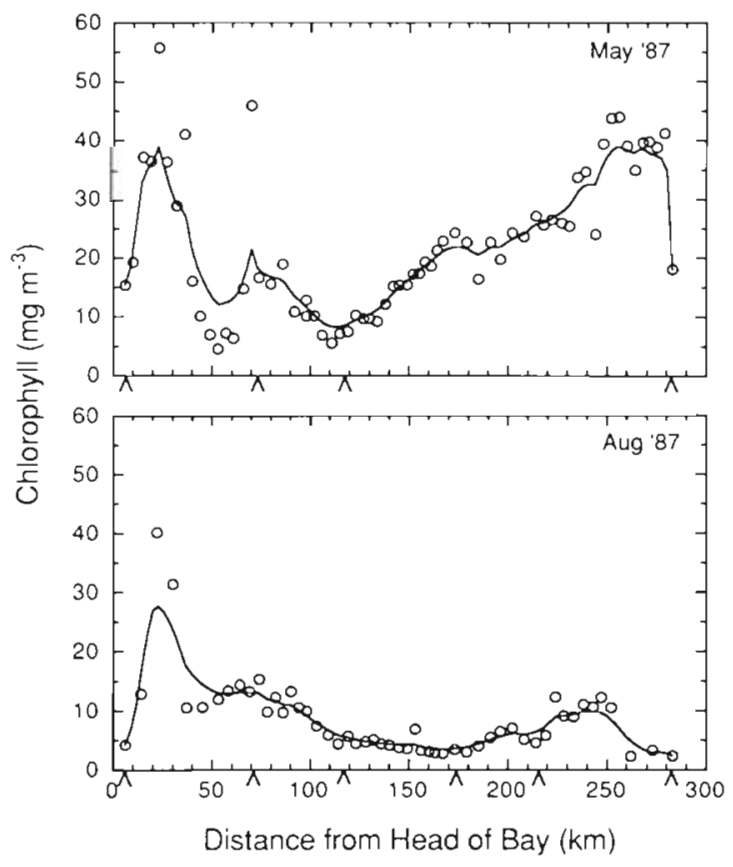

Fig. 5. Spatial distribution of algal biomass as indicated by chlorophyll a in Chesapeake Bay in May and August 1987 Carets under the $x$-axes mark approximate station locations along the length of the Bay

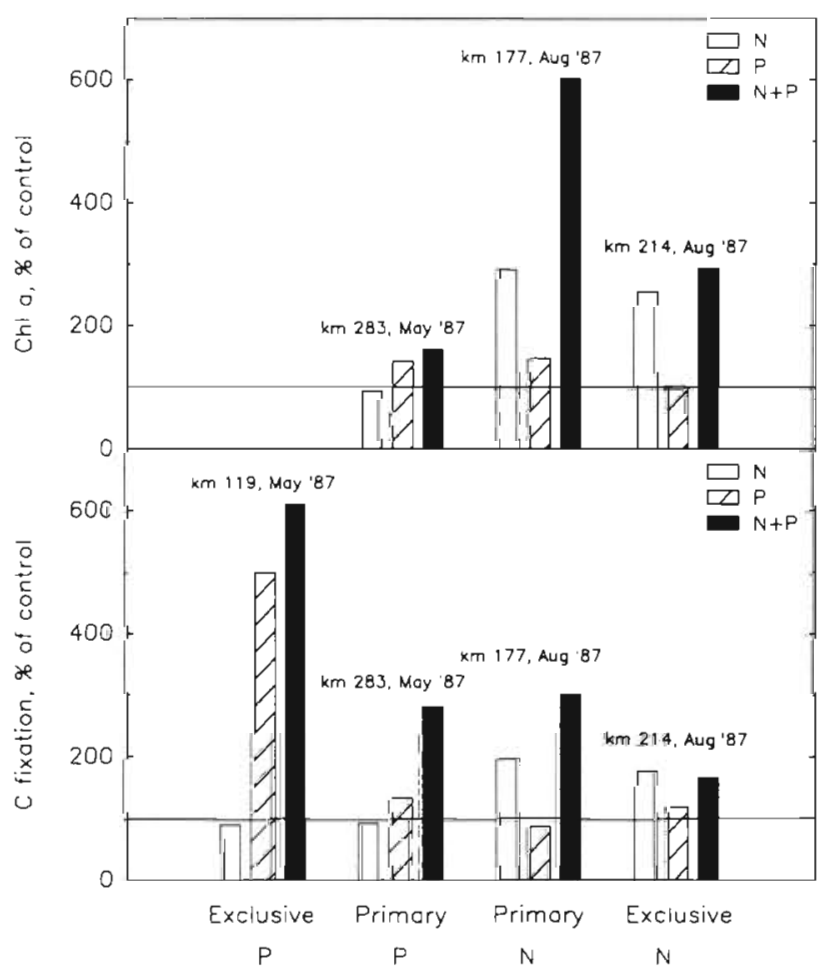

Fig. 6. Examples of algal growth responses in nutrient addition bioassays. Increases in chlorophyll $a$ and carbon fixation following addition of $\mathrm{NH}_{4}$ and/or $\mathrm{PO}_{4}$ were used to test for growth rate limitation of natural phytoplankton assemblages in surface waters of Chesapeake Bay. See text for further description and for definitions of exclusive and primary $\mathrm{P}$ and $\mathrm{N}$ limitation 
Table 3. Summary of nutrient addition bioassays conducted along the major axis of Chesapeake Bay in May and August 1987. Stations are identified by distance from the Susquehanna River mouth $(\mathrm{km})$. Examples of bioassay results are given in Fig. 5 and are defined in the text. In May 1987 bioassay results at the turbid, nutrient-rich station at $\mathrm{km} 6$ showed no response, and no bioassays were performed at $\mathrm{km} 177$ or 214

\begin{tabular}{|rrrrr|}
\multirow{2}{*}{$\mathrm{km}$} & \multicolumn{2}{c}{ May } & \multicolumn{2}{c|}{ August } \\
& Salinity & Bioassay & Salinity & Bioassay \\
\hline 6 & 0.24 & No response & 4.38 & - \\
74 & 7.91 & Exclusive P & 12.22 & Primary N \\
119 & 10.32 & Exclusive P & 13.90 & Primary N \\
177 & 11.77 & - & 15.80 & Primary N \\
214 & 12.67 & - & 19.93 & Exclusive N \\
283 & 15.39 & Primary P & 25.12 & Exclusive N \\
\hline
\end{tabular}

observed (exclusive $N$ limitation; Fig. 6, km 214). The peak in algal biomass near the Susquehanna River in August 1987 (Fig. 5) may have been due to elevated nitrate concentrations (Fig. 3) and alleviation of $\mathrm{N}$ Iimitation in this portion of the Bay

\section{DISCUSSION}

Our results support the hypothesis that seasonal changes occur in the nutrient limiting phytoplankton accumulation in surface waters along the major axis of Chesapeake Bay. Unlike the weak $P$ limitation observed in spring in the Patuxent subestuary by D'Elia et al. (1986), phytoplankton growth rates along the major axis of the Chesapeake appeared to be strongly controlled by $\mathrm{P}$ availability in spring. DIN/PO $\mathrm{P}_{4}$ was typically $>100: 1, \mathrm{PO}_{4}$ turnover times were $<10 \mathrm{~min}$, alkaline phosphatase activities were high and not influenced by $\mathrm{NH}_{4}$ additions, and $\mathrm{PO}_{4}$ additions greatly stimulated growth rates. In contrast, phytoplankton growth rates in summer appeared to be controlled by $N$ availability. DIN $/ \mathrm{PO}_{4}$ was generally $<10: 1$, phosphatase activities were low and stimulated by $\mathrm{NH}_{4}$ additions, and $\mathrm{NH}_{4}$ additions greatly stimulated growth rates. These data suggest that the accumulation of phytoplankton biomass is sequentially limited by $\mathrm{P}$ in spring and by $\mathrm{N}$ in summer

Research in other systems provides useful contrasts with our results. Graneli et al. (1990) have shown that nitrogen primarily controls growth rates and the accumulation of algal biomass in the Baltic Sea. DIN/ $\mathrm{PO}_{4}$ is < 16:1, alkaline phosphatase activity is low, and nutrient enrichment bioassays show primary responses to $\mathrm{N}$. Stimulation by experimental $\mathrm{P}$ additions was only observed following blooms of $\mathrm{N}$-fixing, blue-green algae in the estuarine waters. In Oslofjord, Paasche \&
Erga (1988) showed that the spring diatom bloom was limited by $N$, whereas the flagellate-dominated summer populations were limited by phosphorus. Dissolved nutrient ratios, particulate $C: N$ :P ratios, alkaline phosphatase activity, nutrient uptake parameters, and enrichment bioassays were used to infer a seasonal pattern which was the inverse of our results. In estuarine and coastal waters of China strongly influenced by river runoff, Harrison et al. (1990) presented evidence of spring $\mathrm{P}$ limitation. DIN $/ \mathrm{PO}_{4}$ exceeded 16:1, and nutrient enrichment bioassays showed exclusive $\mathrm{P}$ responses. These studies indicate that there is considerable spatial variability in diluted estuarine and coastal environments with respect to nutrient limitation.

Most of the evidence presented for seasonal variations in nutrient limitation of phytoplankton growth in Chesapeake Bay was obtained at small time and space scales. Our hypothesis, however, addresses biomass accumulation, which is a long-term, large-scale integration of growth rates and includes additional processes in the sediments and water column including grazing, sedimentation, denitrification, etc. Our conclusions do not necessarily extend to the large time and space scales which are addressed by the hypothesis and which are pertinent to management efforts to control eutrophication of the Bay Examination of scaling problems in lakes led Hecky \& Kilham (1988) to conclude that small-scale bioassays of nutrient limitation, such as those reported here, do not necessarily agree with measurements made at larger scales, such as the whole lake manipulations of Schindler (1977). However, large-scale experimental manipulations of estuaries will probably never be practical, and we must consider what evidence exists that the small-scale data on phytoplankton growth rates can be extrapolated to the estuary as a whole on an annual time scale.

We suggest that the best evidence for accurate extrapolation from small to large scales is provided by nutrient concentration data such as those in Figs. $3 \& 4$ The concentrations of $\mathrm{N}$ or $\mathrm{P}$ in the water column reflect the inputs and internal processing of each nutrient within the water column and sediments over large spatial scales and on a time scale equivalent to that of the water residence time (hundreds of kilometers and 6 to 12 mo; Fisher et al. 1988). $\mathrm{PO}_{4}, \mathrm{NH}_{4}$, or $\mathrm{NO}_{3}$ concentrations therefore reflect the integrated sum of riverine, wastewater and oceanic inflows, uptake, sorption, grazing, sedimentation, regeneration, burial, etc. In most cases, the effects of these different processes cannot be distinguished, although mixing diagrams can show the net effect of all of the processes (e.g. Fisher et al. 1988). Furthermore, Graneli et al. (1990) have pointed out that DIN/PO $\mathrm{P}_{4}$ my indicate the potential for nutrient limitation only in winter or spring when 
there is a true accumulation of nutrients; at trace concentrations in summer, rates of recycling determine the availability of $\mathrm{N}$ and $\mathrm{P}$. However, in our data, the $\mathrm{NH}_{4}$ and $\mathrm{PO}_{4}$ turnover data agreed with the DIN/PO

Nevertheless, data such as those in Figs. 3 \& 4 represent an integrated ecosystem response on large time and space scales. The agreement with regard to $\mathrm{N}$ and $\mathrm{P}$ limitation between the nutrient concentration data and nutrient turnover times, dephosphorylation of organic $P$, and nutrient enrichment bioassays measured on smaller time and space scales indicates a concordance of the data at large and small scales. In fact, the growth rate responses probably reflect the state of the ecosystem i.e. the high or low availability of $\mathrm{N}$ relative to $\mathrm{P}$ as a result of all processes. Inconsistencies between the small-scale, growth-related data and the nutrient concentrations would have indicated that scaling effects were important and that processes not included in the small-scale measurements (e.g. grazing, sediment $\mathrm{PO}_{4}$ immobilization) dominated the ecosystem response at larger scales. Our concordant results do not mean that grazing or sediment processes are unimportant; they only indicate that phytoplankton growth rate is the dominant process regulating biomass accumulation. This is supported by Verity (1988) and J. R. White \& M. R. Roman (unpubl.), who have shown that macrozooplankton grazing accounts for $\leq 50 \%$ of the primary production in Chesapeake Bay. The concordance of results at small and large scales also does not mean that processes need not be measured to examine nutrient limitation; process information is essential to understand and support the concentration data.

The conclusion that phytoplankton growth is P limited in spring appears to conflict with the results of other investigators. Boynton et al. (1982) examined annual phytoplankton productivity of several estuaries (including the Chesapeake), and found a significant correlation with $\mathrm{N}$ inputs but not with $\mathrm{P}$. However, annual productivity is dominated by a summer maximum (e.g., Harding et al. 1986, Malone et al. 1988), when $N$ limits growth rates. Therefore, the conclusions of Boynton et al. (1982) are not inconsistent with ours. However, Malone et al. (1988) showed correlations between algal biomass in the mesohaline region of the Chesapeake with both riverine flow and estimated nitrate inputs. There was no significant correlation with estimated phosphorus inputs ( $\mathrm{T}$. C. Malone pers. comm.); the resolution of these differences may be related to the time scales of the investigations.

Silicate is also a major nutrient for phytoplankton. However, we did not measure any processes related to silicate in the research reported here and cannot readily evaluate the potential role of silicate limitation. Nevertheless, in a continuing series of nutrient enrichment bioassays in Chesapeake Bay, we have measured the effects of silicate additions, both alone and in combination with $\mathrm{N}$ and $\mathrm{P}$ (Coley et al. 1990. Fisher et al. 1992). In 1 to $3 \mathrm{~d}$ bioassays, such as those of Fig. 5, we have seen a few responses to additions of silicate alone in the spring, but there were few significant differences between $\mathrm{N}+\mathrm{P}$ and $\mathrm{N}+\mathrm{P}+\mathrm{Si}$ treatments. Since this corresponds to the season when silicate depletion has also been observed, this suggests that silicate limitation can occur, as has been suggested by D'Elia et al. (1983), Harding \& Itsweire (1990), and Conley \& Malone (1992). Data presented here on the distribution of $\mathrm{SiO}_{4}$ and $\mathrm{SiO}_{4} / \mathrm{PO}_{4}$ along the main axis of the Bay (Figs. 3 \& 4) are consistent with a transient limitation of biomass accumulation by $\mathrm{SiO}_{4}$. The coincidence of highest annual phytoplankton biomass with apparent $\mathrm{SiO}_{4}$ limitation makes this recurrent spring event important in the overall sequence of nutrient limitation in Chesapeake Bay (Conley \& Malone 1992) and may be partially responsible for the seasonal shift from a spring diatom maximum to a summer population dominated by flagellates (Sellner 1987). Silicate depletion has been observed in the Great Lakes as a result of P enrichment (Schelske et al. 1983), and the spring depletion of silicate in Chesapeake Bay may have a similar cause.

\section{Explanation of the seasonal cycle}

The basis for shifts in the limiting nutrient can be found in seasonal variations in nutrient inputs. Chesapeake Bay has 4 major sources of $N$ and $P$ (Table 4). Rivers, direct rainfall, and wastewater plants are dominant (US EPA 1982, Magnien et al. 1987, Fisher 1988,1989 ); however, the ocean controls the chemical composition at the seaward end (Fisher et al. 1988). Rivers and rain supply large amounts of $N$ relative to $P$ ( $N / P>90: 1)$ in comparison to the N/P of algal biomass $(16: 1)$. Inputs of river and rain water therefore promote $\mathrm{P}$ limitation due to excess $\mathrm{N}$. In contrast, wastewaters are rich in $\mathrm{P}(\mathrm{N} / \mathrm{P}=7: 1)$, and the excess $\mathrm{P}$ of wastewaters may compensate, in part, for the high $N / P$ of

Table 4. Composition of water sources of Chesapeake Bay. Concentrations are in $\mu \mathrm{M}$, and ratios are by atoms. DIN = dissolved inorganic nitrogen $\left(\mathrm{NH}_{4}+\mathrm{NO}_{2}+\mathrm{NO}_{3}\right), \mathrm{TN}=$ total nitrogen, $\mathrm{PO}_{4}=$ soluble reactive phosphate, $\mathrm{TP}=$ total phosphorus. (Data from Fisher 1988, 1989, Fisher et al. 1988)

\begin{tabular}{|lrrrrrrr|}
\hline Source & DIN & TN & $\mathrm{PO}_{4}$ & $\mathrm{TP}$ & $\begin{array}{c}\mathrm{TN} / \mathrm{TP} \\
\text { RiN/ } \\
\mathrm{PO}_{4}\end{array}$ \\
\hline Rivers & 84. & 130 & 0.4 & 1.4 & 92. & 210 \\
Direct rainfall & 30. & - & 0.1 & - & - & 300 \\
Coastal ocean & 3. & 18. & 0.5 & 1.2 & 15. & 4.0 \\
Wastewaters & 620 & 870 & 83. & 120 & 7.2 & 7.5 \\
\hline
\end{tabular}


river waters (Fisher 1988, 1989). In coastal waters, the concentrations of dissolved inorganic nutrients are usually low, and the residual concentrations are deficient in $N_{i}$ however, total $N$ /total $P$ is nearly equivalent to the N/P of algal biomass.

What seasonal changes shift the balance from $\mathrm{P}$ to $\mathrm{N}$ limitation from spring to summer? Maximum river discharge (with excess $N$ ) occurs in spring whereas minimum discharge occurs in late summer or fall. Inflows of wastewater (with excess P) show no seasonality, and therefore increase in relative importance in summer as freshwater runoff decreases. The N/P of freshwater inputs therefore declines during the spring to summer seasons. As an example, the N/P of all basin inputs declined from ca. 50:1 in winter to $<20: 1$ by late summer in the Choptank River, a subestuary of Chesapeake Bay (Fig. 7). Furthermore, seawater with its balanced N/P intrudes further into estuaries as river discharge decreases (Fig. 1). Summer anoxia also appears to result in substantial releases of $\mathrm{PO}_{4}$ from sediments (Boynton \& Kemp 1985, Cowan et al. 1991), as iron binding sites become saturated with sulphide (Cornwell et al. 1991), although $N$ losses via coupled nitrification/denitrification in sediments are reduced under anoxia in summer (Jenkins \& Kemp 1984). The net effect of all of these processes appears to be a seasonal shift from $P$ limitation under the influence of the peak discharge of river water in spring, to $N$ limitation under summer conditions of reduced river inflows, higher salinity, the greater importance of wastewater inputs, and sediment anoxia (Table 5). We suggest that variations in the relative importance of processes listed in Table 5 may provide an explanation for the spatial variations in nutrient limitation of other aquatic systems (e.g. freshwater lakes, the Baltic and China coastal seas, as discussed above).

\section{Management considerations}

The nutrient management of Chesapeake Bay must consider carefully the annual cycle of phytoplankton growth. There is a spring accumulation of diatoms that sediments from the surface layer, is microbially metabolized, and contributes to bottom water anoxia and subsequent nutrient fluxes from sediments (Malone et al. 1986). This peak in algal abundance

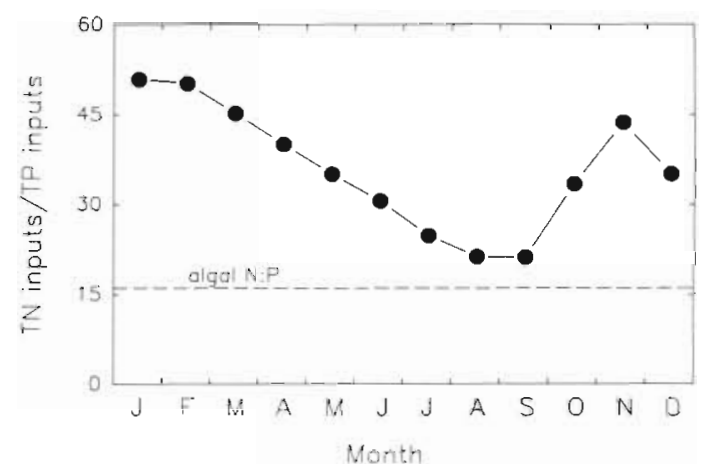

Fig. 7. An example of the seasonal decline in the atomic N:P of nutrient inputs from a study of the basin of the Choptank River, a subestuary of Chesapeake Bay (Fisher 1988). Inputs from the entire basin were volume-weighted and computed from total $\mathrm{N}$ and $\mathrm{P}$ of direct rainfall, surface stream runoff, and the combined discharges of 10 wastewater treatment plants over water years 1980 to 1987

Table 5. Conceptual model of the basis for seasonal changes in nutrient limitation of algal biomass in Chesapeake Bay

\begin{tabular}{|c|c|c|c|}
\hline & Spring & Summer & Source \\
\hline Inputs: & $\begin{array}{l}\text { River discharge dominates } \\
\text { Lower salinities } \\
\text { Excess } N \text { available }\end{array}$ & $\begin{array}{l}\text { Wastewater, seawater more important } \\
\text { Higher salinities } \\
\mathrm{N} \text { and } \mathrm{P} \text { inputs decreased } \\
\mathrm{P} \text { increased relative to } \mathrm{N} \\
\text { due to sewage }\end{array}$ & $\begin{array}{l}\text { Fisher (1988) } \\
\text { Present study } \\
\text { Present study } \\
\text { Fisher (1988) }\end{array}$ \\
\hline Sediments: & $\begin{array}{l}\text { Oxygenated } \\
\mathrm{PO}_{4} \text { sorption and storage } \\
\text { Coupled nitrification and } \\
\text { denitrification }\end{array}$ & $\begin{array}{l}\text { Anoxic } \\
\mathrm{PO}_{4} \text { release } \\
\text { Decoupled }\end{array}$ & $\begin{array}{l}\text { Boynton \& Kemp (1985) } \\
\text { Boynton \& Kemp (1985) } \\
\text { Jenkins \& Kemp (1984) }\end{array}$ \\
\hline Algal biomass: & $\begin{array}{l}\text { P-limited } \\
\text { Diatoms dominate } \\
\text { Si controls taxonomy } \\
\text { Biomass maximum } \\
\text { Sedimentation high } \\
\text { Organic decomposition creates } \\
\text { summer anoxia }\end{array}$ & $\begin{array}{l}\text { N-limited } \\
\text { Flagellates dominate } \\
\text { Si unimportant } \\
\text { Productivity maximum } \\
\text { Sedimentation low } \\
\text { Biomass turns over rapidly } \\
\text { in water column }\end{array}$ & $\begin{array}{l}\text { Present study } \\
\text { Sellner (1987) } \\
\text { Conley \& Malone (1992) } \\
\text { Malone et al. (1988) } \\
\text { Malone et al. (1986) } \\
\text { Malone et al. (1986) }\end{array}$ \\
\hline
\end{tabular}


appears to be regulated by the availability of $\mathrm{PO}_{4}$ and perhaps $\mathrm{SiO}_{4}$. Summer phytoplankton populations are dominated by microflagellates which largely remain in surface waters (Boynton et al. 1982, Malone et al. 1986, Sellner 1987, Malone et al. 1988). Biomass during summer appears to be regulated by availability of DIN.

$N$ and $P$ reductions in inflowing waters will have important consequences for Chesapeake Bay, P reductions will control the abundance of the spring diatoms, thereby reducing (1) sedimenting biomass, (2) the severity of summer anoxia, and (3) recycling of $\mathrm{N}$ and $\mathrm{P}$ to overlying waters in summer. $N$ reductions will (1) decrease the zone of excess DIN in spring and (2) directly reduce algal biomass in summer. Algal biomass in summer should be controlled both by $\mathrm{N}$ reductions in inflowing waters as well as reduced amounts of $\mathrm{N}$ recycled from spring populations. The reductions in planktonic algae will increase water transparency and improve growth conditions for submerged aquatic vegetation in the Bay. Because of the long residence time of water in the Chesapeake Bay (Fisher et al. 1988), withholding of $\mathrm{N}$ or $\mathrm{P}$ seasonally is probably not a viable strategy, whereas locally designed reductions of $\mathrm{N}$ and $\mathrm{P}$ should provide effective control of eutrophication. Similar conclusions have been reached by Graneli et al. (1990) for the Baltic Sea, a large estuary with eutrophication problems similar to those of the Chesapeake.

Management must also consider local drainage basin characteristics. Differences between the results reported here and those of D'Elia et al. (1986) and Webb (1988) strongly support implementation of individual strategies for each drainage basin. There are varying nutrient inputs via rain, runoff, and sewage, and important differences in biogeochemical processing via uptake, sedimentation, and diagenesis which can clearly produce varying ecosystem responses. Investigations of basin-scale inputs and internal processing in subestuaries of the Chesapeake, and implementation of local management strategies, represent an opportunity to test ecosystem responses in estuaries on a scale similar to that which has been used for lakes.

Acknowledgements. We thank C. F. D'Elia, D. R. S. Lean, T C. Malone, R. Rivkin, E. Paasche, and an anonymous reviewer for constructive comments on earlier drafts of this manuscript. R. D. Doyle, M. Mallonee, and S. Pearce provided valuable technical assistance. Supported by NSF OCE 82-03962 to T.R.F., NSF BSR 88-14272 to T.R.F. and E.R.P, NSF OCE 8518401 to J.W.A., NSF OCE 83-10407 to L.W.H., and MD Sea Grant NA86AA-D-SG006 to T C. Malone.

\section{LITERATURE CITED}

Ammerman, J. W., Azam, F. (1985). Bacterial 5'-nucleotidase in aquatic ecosystems: a novel mechanism of phosphorus regeneration. Science 227: 1338-1340
Ammerman, J. W., Azam, F. (1991). Bacterial 5'-nucleotidase activity in estuarine and coastal marine waters: characterization of enzyme activity. Limnol. Oceanogr. 36: $1427-1436$

Boynton, W R., Kemp, W. M. (1985). Nutrient regeneration and oxygen consumption by sediments along an estuarine salınity gradient. Mar Ecol. Prog. Ser 23: 45-55

Boynton, W. R., Kemp, W. M., Keete, C. W. (1982). A comparative analysis of nutrients and other factors influencing estuarine phytoplankton production. In. Kennedy, V S (ed.) Estuarine comparisons. Academic Press, New York, p. $69-90$

Brush, G. S., Davis, F. W (1984). Stratigraphic evidence of human disturbance in an estuary. Quarternary Res. 22: $91-108$

Caraco, N. (1988). What is the mechanism behind the seasonal switch between $\mathrm{N}$ and $\mathrm{P}$ limitation in estuaries? Can. J. Fish. Aquat. Sci. 45: 381-383

Caraco, N., Cole, J., Likens, G. E. (1990). A comparison of phosphorus immobilization in sediments of freshwater and coastal marine systems. Biogeochemistry 9: $277-290$

Caraco, N., Tamse, A., Boutros, O., Valiela, I. (1987). Nutrient limitation of phytoplankton growth in brackish coastal ponds. Can. J. Fish. Aquat Sci. 44: 473-476

Cembella, A. D., Antia, J. J., Harrison, P. J. (1984). The utilization of inorganic and organic phosphorus compounds as nutrients by eukaryotic microalgae: a multidisciplinary perspective. Part 1. CRC crit. Rev. Microbiol. 10: 317-391

Coley, T., Peele, E., Fisher, T. R. (1990). Nutrient limitation of Chesapeake Bay phytoplankton. Abstract. Am. Soc. Limnol. Oceanogr. Proc. June 1990. Williamsburg, VA

Conley, D. J., Malone, T C. (1992). Annual cycle of dissolved silicate in Chesapeake Bay: implications for the production and fate of phytoplankton biomass. Mar Ecol. Prog. Ser. 81. $121-128$

Cooper, S. R., Brush, G. S. (1991). Long-term history of Chesapeake Bay anoxia. Science 254: 992-996

Cornwell, J., Boynton, W R., Owens, M., Cowan, J. (1991). Phosphorus cycling in Chesapeake Bay sediments: control by iron and sulfur diagenesis. Abstract. Estuarine Research Fed. Proc., Nov. 1991 San Francisco

Cowan, J. L. W., Boynton, W R., Cornwell, J. C., Rosman, L., Kemp, W. M. (1991). Sediment-water exchanges of nutrients and oxygen along an estuarine salinity gradient. Abstract. Estuarine Research Fed. Proc., Nov. 1991. San Francisco

D'Elia, C. F., Nelson, D. M., Boynton, W. R. (1983). Chesapeake Bay nutrient and plankton dynamics: III. The annual cycle of dissolved silicon. Geochim. cosmochim. Acta 47 1945-1955

D'Elia, C. F., Sanders, J. G., Boynton, W. R. (1986). Nutrient enrichment studies in a coastal plain estuary: phytoplankton growth in large-scale, continuous cultures. Can. J. Fish. Aquat. Sci. 43: 397-406

Domotor, D., Haire, M. S., Panday, N. N., Summers, R. N (1989). Patuxent estuary water quality assessment: special emphasis 1983-1987. Tech. Rep. No. 104 MD Dept of the Environment, Baltimore

Edmondson, W. T (1970). Phosphorus, nitrogen, and algae in Lake Washington after diversion of sewage. Science 169 : 690-691

Fisher, T R. (1988). N and P loading of the Choptank River: point and diffuse sources. Final Rep. MD Dept. Nat. Res. Contr C29-87-024. Annapolis, MD

Fisher, T R. (1989). Nutrient inputs to the Choptank River. 
Final Rep. US Fish Wildlife Serv. Coop. Agree. 14-16-000586-9035. Annapolis, MD

Fisher, T. R., Morrissey, K. M. (1985). A new method for the recovery of ammonium from natural waters for measurement of ${ }^{15} \mathrm{~N}$ composition in isotope dilution experiments. Mar Chem. 16:11-21

Fisher, T R., Harding, L. W., Stanley, D. W., Ward, L. G. (1988). Phytoplankton, nutrients, and turbidity in the Chesapeake, Delaware, and Hudson estuaries. Estuar coast. Shelf Sci. 27: 61-93

Fisher, T. R., Gustafson, A. B., Sellner, K. G., Lacouture, R. B. (1992). Nutrient bioassays in Chesapeake Bay to assess nutrients limiting algal growth. Progress Rep. MD Dept. of the Environment, Jan 1992, Baltimore

Graneli, E., Wallstrom, K., Larsson, U., Graneli, W., Elmgren, R. (1990). Nutrient limitation of primary production in the Baltic Sea area. Ambio 19: 142-151

Harding, L. W., Itsweire, E. C. (1990). Synoptic measurements of the distribution of chlorophyll in the Chesapeake Bay using aircraft remote sensing. In: Mihursky, J. A., Chaney, A. (eds.) New perspectives in the Chesapeake system: a research and management partnership. Ches. Res. Consort. Pub. No. 137. Baltimore, p. 147-160

Harding, L. W., Meeson, B. W., Fisher, T R. (1986). Phytoplankton production in two East Coast estuaries: photosynthesis-light functions and patterns of carbon assimilation in Chesapeake and Delaware Bays. Estuar. coast. Shelf Sci. 23: 773-806

Harrison, P. J., Hu, M. H., Yang, Y P., Lu, X. (1990). Phosphate limitation in estuarine and coastal waters of China. J. exp. mar Biol. Ecol. 140: 79-87

Hecky, R. E., Kilham, P. (1988). Nutrient limitation of phytoplankton in freshwater and marine environments: a review of recent evidence on the effects of enrichment. Limnol. Oceanogr. 33: 796-822

Hoppe, H.-G. (1983). Significance of exoenzymatic activities in the ecology of brackish water: measurements by means of methylumbelliferyl-substrates. Mar Ecol. Prog. Ser. 11. 299-308

Howarth, R. W. (1988). Nutrient limitation of net primary production in marine ecosystems. Ann. Rev. Ecol. Syst. 19 89-110

Jenkins, M. C., Kemp, W. M. (1984). The coupling of nitrification and denitrification in two estuarıne sediments. Limnol. Oceanogr 29: 609-619

Jordan, T E., Correll, D. L., Miklas, J, Weller, D. E. (1991). Nutrients and chlorophyll at the interface of a watershed and an estuary. Limnol. Oceanogr 36: 251-267

Lean, D. R. S. (1973). Movements of phosphorus between its biologically important forms in lake water. J. Fish. Res. Bd Can. 30: 1525-1536

Lean, D. R. S., Abbott, A. A., Pick, F R. (1987). Phosphorus deficiency of Lake Ontario phytoplankton. Can. J. Fish. Aquat. Sc1. 44: 2069-2076

Lean, D. R. S., Pick, F. R., Mitchell, S. F., Downes, M. T., Woods, P. H., White, E. (1989). Lake Okaro enclosure experiments: test ecosystems to evaluate plankton phosphorus and nitrogen deficiency. Arch. Hydrobiol. (Beih. Ergebn. Limnol). 32: 195-211

Lorenzen, C. J. (1967). Determination of chlorophyll and pheopigments: spectrophotometric equations. Limnol. Oceanogr 12: 343-346

Magnien, R. E., Summers, R. M., Haire, M. S., Boynton, W. R., Brownlee, D. C., Holland, A. F., Jacobs, F., Kemp, W M., Sellner, K. G., Foster, G. D., Wright, D. A. (1987). Monitoring for management actions. Chesapeake Bay Water Qual- ity Monitoring Rep., Feb 1987 MD Office of Environ Programs, Baltimore

Malone, T. C., Crocker, L. H., Pike, S. E., Wendler, B. W (1988). Influences of river flow on the dynamics of phytoplankton production in a partially stratified estuary. Mar Ecol. Prog. Ser. 48: 235-249

Malone, T C., Kemp, W. M., Ducklow, H. W., Boynton, W. R., Tuttle, J. H. Jonas, R. B. (1986). Lateral variation in the production and fate of phytoplankton in a partially stratified estuary. Mar. Ecol. Prog. Ser. 32: 149-160

Nixon, S. W (1987). Chesapeake Bay nutrient budgets a reassessment. Biogeochemistry 4: 77-90

Oglesby, R. T., Schaffner, W. R. (1978). Phosphorus loadings to lakes and some of their responses. Part 2 . Regression models of summer phytoplankton standing crops, winter total P, and transparency of New York lakes with known phosphorus loadings. Limnol. Oceanogr. 23: 135-145

Orth, R. J., Moore, K. A. (1983). Chesapeake Bay: an unprecedented decline in submerged aquatic vegetation. Science 222: 51-53

Paasche, E., Erga, S. R. (1988). Phosphorus and nitrogen limitation of phytoplankton in the inner Oslofjord (Norway). Sarsia 73: 229-243

Rigler, F. (1966). Radiobiological analysis of inorganic phosphorus in lakewater Verh. int. Verein. Limnol. 16 $465-470$

Rigler, F. (1973). A dynamic view of the phosphorus cycle in lakes. In: Griffith, E. J (ed.) The environmental phosphorus handbook. John Wiley \& Sons, New York, p $539-568$

Schelske, C. I., Stoermer, E. F., Conley, D. J., Robbins, J. A. Glover, R. M. (1983). Early eutrophication in the lower Great Lakes: new evidence from biogenic silica in sediments. Science 222: 320-322

Schindler, D. W (1977). Evolution of phosphorus limitation in lakes. Science 195: 260-262

Seliger, H. H., Boggs, J. A., Biggley, W H. (1985). Catastrophic anoxia in the Chesapeake Bay in 1984 . Science 228: 70-73

Sellner, K. G. (1987). Phytoplankton in Chesapeake Bay: role in carbon, oxygen, and nutrient dynamics. In: Majumdar, S. K. Hall, L. W. Jr, Austin, H. M. (eds.) Contaminant problems and management of living Chesapeake Bay resources. Pennsylvania Academy of Sciences, Philadelphia, p. 134-157

Smith, V H. (1982). The nitrogen and phosphorus dependence of algal biomass in lakes: an empirical and theoretical analysis. Limnol. Oceanogr 27: 1101-1112

Smith, S. V (1984). Phosphorus versus nitrogen limitation in the marine environment. Limnol. Oceanogr. 29: 1149-1160

Taft, J. L., Elliott, A. J., Taylor, W. R. (1978). Box model analysis of Chesapeake Bay ammonium and nitrate fluxes In: Wiley, M. L. (ed.) Estuarine interactions. Academic Press, New York, p. 115-130

Taft, J. L, Loftus, M. E., Taylor, W. R. (1977). Phosphate uptake from phosphomonoesters by phytoplankton in the Chesapeake Bay. Limnol. Oceanogr. 22: 1012-1021

Taft, J. L., Taylor, W. R. (1976a). Phosphorus distribution in the Chesapeake Bay. Chesapeake Sci. 17.67-73

Taft, J. L., Taylor, W. R. (1976b). Phosphorus dynamics in some coastal plain estuaries. In: Cronin, L. E. (ed.) Estuarine processes, Vol 1. Academic Press, New York, p. $79-89$

Taft, J. L., Taylor, W R., McCarthy, J. J. (1975). Uptake and release of phosphorus by phytoplankton in the Chesapeake Bay estuary, USA. Mar Biol. 33: 21-32 
US EPA (Environmental Protection Agency) (1982) Chesapeake Bay Program Technical Studies. US EPA, Washington, D.C.

US Geological Survey (1987). Water Resources Data. Maryland and Delaware. Water Year 1987 US Geological Survey. Water-Data Rep. MD-DE-87-1 Towson, MD

Verity, P. G. (1988). The trophic structure of pelagic communities: hypotheses and problems. In: Lynch, M. P. Krome, E. C. (eds.) Understanding the estuary: advances

This article was presented by D. K. Stoecker, Cambridge, Maryland, USA in Chesapeake Bay Research. Ches. Res. Consort. Pub. No 129. Baltimore, p. 49-54

Vollenweider, R. A. (1968). Scientific fundamentals of lakes and flowing waters, with particular reference to nitrogen and phosphorus as factors in eutrophication. OECD Tech Rep. DAS/C51/68.27 UNESCO, Paris

Webb, K. L. (1988). Comment on Nutrient limitation of phytoplankton growth in brackish coastal ponds by Caraco Tamse, Boutros, and Valiela (1987). Can. J. Fish. Aquat. Sci. 45: 380

Manuscript first received: December 6, 1991 Revised version accepted: March 10, 1992 